\title{
Telomerase activity in B and T lymphocytes of patients with systemic lupus erythematosus
}

\author{
W Klapper, F Moosig, A Sotnikova, W Qian, J O Schröder, R Parwaresch
}

Ann Rheum Dis 2004;63:1681-1683. doi: 10.1136/ard.2003.016022

Objective: To evaluate telomerase activity as a marker of lymphocyte proliferation in systemic lupus erythematosus (SLE).

Methods: CD19+, CD4+, and CD8+ lymphocytes were isolated from the peripheral blood of nine patients with SLE and nine healthy controls by means of magnetic beadcoupled antibodies and tested for telomerase activity with the TRAP assay.

Results: Telomerase activity was significantly increased in CD19+ B cells from patients with SLE. CD4+ and CD8+ T cells from lupus patients displayed increased mean telomerase activity, although the difference from normal controls did not reach statistical significance.

Conclusions: Increased telomerase activity in the B and the T cell lineage might indicate activation and proliferation of these lymphocytes.

$\mathrm{T}$ elomeres, the natural ends of chromosomes, shorten with each cell division and thus function as a "mitotic clock". Critically shortened telomeres force cells to irreversibly exit the cell cycle and enter a state called "senescence". Immortal cells, such as germ line cells, stem cells, and tumour cells, express the enzyme telomerase, which adds new telomeric repeats to the chromosomal ends to compensate for telomere loss. ${ }^{1}$ Cells with a high regenerative capacity, like epithelial cells and stem cells, can up regulate telomerase activity by proliferative stimulation. ${ }^{23}$

$\mathrm{B}$ and $\mathrm{T}$ lymphocytes stimulated to proliferate in vitro up regulate telomerase activity and slow down their telomere shortening, although they cannot prevent it completely. ${ }^{2}$ Thus telomerase activity is a marker of proliferative stimulation of lymphocytes. Telomere shortening, on the other hand, represents a marker for the replicative history of lymphocytes and is considered to contribute to the aging process of the immune system. ${ }^{45}$

Studies on $\mathrm{T}$ cells from patients with rheumatoid arthritis, atopic dermatitis, and psoriasis showed telomere shortening in CD4+ cells in all diseases and, additionally, in CD8+ cells in atopic dermatitis and psoriasis. ${ }^{6}$ Increased telomerase activity was detected in the T cells in atopic dermatitis and psoriasis. ${ }^{7}$ It has been suggested that $\mathrm{T}$ lymphocytes in rheumatoid arthritis, atopic dermatitis, and psoriasis are stimulated to proliferate and this stimulation is reflected by an increase in telomerase activity. The accelerated telomerase activity seems insufficient to counteract the enhanced telomere shortening in these diseases. Thus the supposed increased T cell turnover in rheumatoid arthritis, atopic dermatitis, and psoriasis induces accelerated replicative aging of the immune system.

To gain insights into the activation status and the turnover of lymphocytes in systemic lupus erythematosus (SLE), we measured telomerase activity and telomere length in freshly isolated CD4+, CD8+, and CD19+ lymphocytes from patients with SLE in comparison with their counterparts in healthy donors.

\section{METHODS}

Samples were obtained from nine female patients with SLE (diagnosed according to the criteria of the American College of Rheumatology) and from nine healthy age matched female controls, with informed consent. Table 1 shows the patients' data. Infection was ruled out by low to moderate $\mathrm{C}$ reactive protein (CRP) serum levels (table 1 ).

Peripheral blood mononuclear cells were purified on a Ficoll gradient. Magnetic bead-coupled antibodies directed against CD19, CD4, and CD8 were used to positively select for $\mathrm{B}$ and $\mathrm{T}$ cells, respectively, by magnetic cell sorting. Telomerase activity was determined using $300 \mathrm{ng}$ protein extract and a semiquantitative telomerase activity assay, as described previously. ${ }^{8}$ Minor variations were introduced into the assay to increase the sensitivity: in each assay 30 pmol TS primer and 40 polymerase chain reaction cycles were used.

For semiquantitative measurement a dilution series of HeLa cell extract was analysed in parallel. A linear regression analysis of the telomerase peak/internal telomere repeat amplification standard ratios of the dilution series was performed (GraphPad Prism). The experimental samples were expressed as corresponding nanograms of HeLa protein. This quantification method takes the slope of the standard curve into account. The generated values can be compared with each other easily and directly, because an increase-for example, from $3 \mathrm{ng}$ to $6 \mathrm{ng}$, truly reflects a doubling of the activity. Statistical analysis was performed using GraphPad Prism for Windows.

Telomere length was determined by measuring the terminal restriction fragment length using the Southern blot method (TeloTTAGGG telomere length assay; Roche). Blots were scanned and analysed densitometrically using the software Quantity One (BioRad). The areas of highest signal intensity were correlated with the length standard that was included on each gel.

\section{RESULTS}

Using a highly sensitive assay for telomerase activity which can detect a single telomerase positive HeLa cell, we found telomerase activity in almost all lymphocytes in healthy donors (9/9 for CD4+, 7/8 for CD8+, 8/8 for CD19+). Although the activity was very low (30-60 times less than HeLa tumour cells), CD4+ cells showed the highest activity (mean (SD) 4.2 (1.4) ng), whereas CD8+ cells (2.0 (1.2) ng) and CD19+ cells (1.9 (1.7) ng) displayed similar activity levels (fig l). Telomerase activity in SLE samples exhibited a distribution pattern comparable to that in healthy donors, with the highest levels in CD4+ cells (7.1 (3.0) ng) and similar levels in CD8+ (4.1 (3.5) ng) and CD19+ (5.9 (3.9) ng) lymphocytes. Although the mean values differed between patients with SLE and healthy controls in CD4+ and CD8+ cells, a Kruskal-Wallis test showed that the differences were not 
Table 1 Clinical characterisation of the nine patients with SLE

\begin{tabular}{|c|c|c|c|c|c|c|c|c|c|c|c|c|c|c|c|}
\hline \multirow{2}{*}{$\begin{array}{l}\text { Patient } \\
1\end{array}$} & \multicolumn{2}{|c|}{$\begin{array}{l}\text { Duration ANA } \\
\text { (months) titre }\end{array}$} & \multirow{2}{*}{$\begin{array}{l}\begin{array}{l}\text { Anti- dsDNA } \\
\text { titre }\end{array} \\
\text { Neg }\end{array}$} & \multirow{2}{*}{$\begin{array}{l}\begin{array}{l}\text { Anti-Ro } \\
\text { titre }\end{array} \\
133 \\
\end{array}$} & \multirow{2}{*}{$\begin{array}{l}\begin{array}{l}\text { Anti-La } \\
\text { titre }\end{array} \\
20\end{array}$} & \multirow{2}{*}{$\begin{array}{l}\text { Leucocytes } \\
\left(\times 10^{9} / \mathrm{I}\right)\end{array}$} & \multirow{2}{*}{$\begin{array}{l}\begin{array}{l}\text { Lymphocytes } \\
\left(\times 10^{9} / \mathrm{l}\right)\end{array} \\
3.4\end{array}$} & \multirow{2}{*}{$\begin{array}{l}\begin{array}{l}\mathrm{Hb} \\
(\mathrm{g} / \mathrm{l})\end{array} \\
146\end{array}$} & \multirow{2}{*}{$\begin{array}{l}\begin{array}{l}\text { Thrombo- } \\
\text { cytes } \\
\left(\times 10^{3} / \mu l\right)\end{array} \\
272\end{array}$} & \multirow{2}{*}{$\begin{array}{l}\begin{array}{l}\text { ESR } \\
(\mathrm{mm} / 1 \mathrm{st} h)\end{array} \\
11\end{array}$} & \multirow{2}{*}{$\begin{array}{l}\begin{array}{l}\text { CRP } \\
\text { (mg/l) }\end{array} \\
11.7\end{array}$} & \multirow{2}{*}{$\begin{array}{l}\text { C3 } \\
\text { (g/l) }\end{array}$} & \multirow{2}{*}{$\begin{array}{l}\begin{array}{l}\text { C4 } \\
\text { (g/l) }\end{array} \\
0.17\end{array}$} & \multirow{2}{*}{$\begin{array}{l}\text { Actual treatment } \\
\mathrm{HCQ}, \mathrm{PRED}\end{array}$} & \multirow{2}{*}{$\begin{array}{l}\text { SLAM } \\
2\end{array}$} \\
\hline & 13 & 2560 & & & & & & & & & & & & & \\
\hline 2 & 13 & 5120 & 15 & Neg & Neg & 8.6 & 1.7 & 140 & 371 & 30 & 8.3 & 1.28 & 0.22 & PRED & 7 \\
\hline 3 & 15 & 20480 & 121 & 200 & 200 & 7.1 & 1.8 & 121 & 255 & 11 & 3.5 & 0.94 & 0.11 & PRED & 4 \\
\hline 4 & 72 & 20480 & 449 & 200 & 189 & 9 & 2.3 & 122 & 362 & 19 & 3.5 & 0.66 & 0.06 & HCQ, PRED & 6 \\
\hline 5 & 10 & 5120 & 251 & $\mathrm{Neg}$ & $\mathrm{Neg}$ & 3.9 & 1.1 & 117 & 306 & 19 & 3.5 & 0.84 & 0.1 & CYC, PRED & 5 \\
\hline 6 & 180 & 20480 & Neg & Neg & $\mathrm{Neg}$ & 7 & 1.5 & 114 & 257 & 21 & 3.5 & 0.55 & 0.06 & $H C Q, A Z A, P R E D$ & 7 \\
\hline 7 & 58 & 10240 & 335 & 200 & 200 & 4.3 & 0.8 & 129 & 429 & 30 & 22.9 & 1.23 & 0.12 & $\mathrm{HCQ}, \mathrm{MFM}, \mathrm{PRED}$ & 8 \\
\hline 8 & 24 & 10240 & $\mathrm{Neg}$ & 200 & 40 & 4.5 & 0.9 & 140 & 167 & 22 & 3.5 & 1.08 & 0.08 & NSAID & 7 \\
\hline 9 & 14 & 10240 & 706 & $\mathrm{Neg}$ & $\mathrm{Neg}$ & 4.7 & 0.7 & 124 & 164 & 57 & 8.2 & 0.58 & 0.05 & CYC, PRED & 9 \\
\hline
\end{tabular}

Neg, Negative; HCQ, hydroxychloroquine, PRED: prednisolone; CYC, cyclophosphamide; AZA: azathioprine; MFM, mycophenolatmofetile; NSAID, non-steroidal anti-inflammatory drug.

significant ( $\mathrm{p}>0.05$; fig 1$)$. However, telomerase activity was significantly increased in SLE CD19+ cells compared with normal donors $(\mathrm{p}<0.05$, Kruskal-Wallis test, Dunn's multiple comparison test; fig 1).

To test whether telomerase activation can prevent telomere shortening in the lymphocyte subsets in SLE, we measured telomere length in these cells. Owing to frequent lymphopenia in patients with SLE, only small cell numbers could be recovered from the blood (table 1). Thus only a few samples yielded enough genomic DNA to perform Southern blotting. We were able to examine telomere length in CD4+ cells from five healthy donors and six patients with SLE. The telomere length of CD8+ cells was analysed in five healthy donors and five patients with SLE. We found no significant telomere shortening. Figure 2 shows a representative blot.

\section{DISCUSSION}

In contrast with previous reports, which dealt only with telomerase activation in peripheral blood mononuclear cells from patients with SLE, ${ }^{10}$ we measured telomerase activity quantitatively in purified lymphocyte subgroups. Because monocytes and granulocytes have been shown to have no telomerase activity, the experimental approach used in this study should most precisely reflect the in vivo situation. Our findings demonstrate that in SLE, telomerase activity is increased in both $\mathrm{B}$ and $\mathrm{T}$ cells. Because telomerase up regulation in lymphocytes is induced by different proliferative stimuli in vitro, ${ }^{4}$ the accelerated telomerase activity in SLE is probably caused by constitutive in vivo stimulation and higher proliferation. The increase in the mean telomerase activity in SLE compared with healthy controls was apparent for all lymphocyte subpopulations studied here. However, statistical significance was only detected for CD19+ B cells. In patients with SLE, B cell homoeostasis is disturbed, ${ }^{11}$ whereas in other rheumatic diseases, such as rheumatoid arthritis and Wegener's granulomatosis, abnormal expansion of $\mathrm{T}$ cell populations has been described. ${ }^{12}$ It will thus be of future

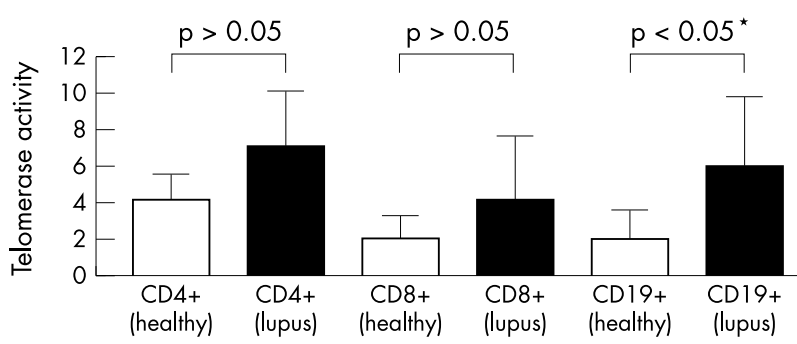

Figure 1 Telomerase activity measured by the TRAP assay. For semiquantitative analysis a dilution series of Hela extract was assayed in parallel. The experimental samples were expressed as corresponding nanograms of HeLa protein. Mean and standard deviation are indicated.

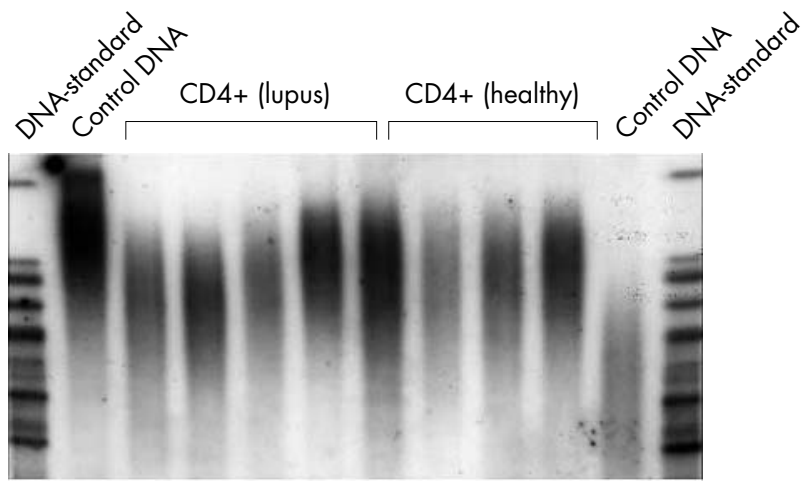

Figure 2 Telomere length was determined by measuring the terminal restriction fragment length using the Southern blot method (TeloTTAGGG telomere length assay, Roche). A representative blot for CD4+ cells is shown. A DNA ladder and control DNA with long telomeres (left side) and short telomeres (right side) are included on the blot. Owing to their heterogeneity, telomere restriction fragments appear as smears on the blot.

interest whether the observed high telomerase activity results from the naive or the memory B cell population.

Telomere shortening occurs during replicative aging of somatic cells and causes genetic instability as well as irreversible exit from the cell cycle ("senescence") and might thus contribute to tissue aging. ${ }^{4}$ No telomere shortening could be detected in lymphocytes from patients with SLE. It has been clearly shown that increased telomerase activity can overcome telomere shortening. ${ }^{13}$ We suggest that in lymphocytes of SLE, telomerase activity might be sufficient to compensate for the telomere loss that occurs during proliferation and thus prevent accelerated aging of the immune system in these patients. We cannot rule out the presence of other mechanisms, such as alterations in telomere binding protein expression, which alone or together with the observed high telomerase activity contribute to telomere maintenance in SLE. However, because telomere length has been determined in only a small number of CD4+ and CD8+ samples and a high degree of variation in telomere length has been reported in healthy donors, these data have to be considered preliminary, especially because the telomere length variations might not occur until after an extended disease duration.

As increased telomerase activity follows proliferative stimulation of lymphocytes in vitro, ${ }^{4}$ the results presented here suggest that telomerase activity is a marker of lymphocyte proliferation in SLE. On the one hand, CD4+ and CD8+ memory after viral infection show diverse population dynamics, ${ }^{14}$ and on the other, it has been suggested that telomerase controls the lifespan of T lymphocytes. ${ }^{15}$ It will thus be interesting to determine telomerase 
activity in CD4+ and CD8+ memory cells from patients with SLE as well as after viral infection. Nevertheless, larger sample numbers are needed to correlate telomere length and telomerase activity with clinical measures of disease activity and duration in order to be able to evaluate the clinical significance. These future studies should analyse telomerase activity and telomere length in purified lymphocyte subgroups because our data indicate that the extent of telomerase activation differs between $\mathrm{B}$ and $\mathrm{T}$ cells.

\section{ACKNOWLEDGEMENTS}

This study was supported in part by the Kinder-Krebs-Initiative Buchholz-Holm-Seppensen and the Hensel-Stiftung of the University of Kiel.

\section{Authors' affiliations}

W Klapper, A Sotnikova, W Qian, R Parwaresch, Department of Haematopathology and Lymph Node Registry Kiel, University Kiel Niemannsweg 11, 24105 Kiel, Germany

F Moosig, J O Schröder, Second Department of Internal Medicine, University Kiel, Chemnitzstr 33, 24107 Kiel, Germany W Qian, Department of Haematology, First affiliated Hospital of Zhejiang University, Qianchun Road 79, Hangzhou 310003, China

Correspondence to: Dr W Klapper, wklapper@path.uni-kiel.de

Accepted 17 February 2004

\section{REFERENCES}

1 Harley CB, Vaziri H, Counter CM, Allsopp RC. The telomere hypothesis of cellular aging. Exp Gerontol 1992;27:375-82.
2 Buchkovich KJ, Greider CW. Telomerase regulation during entry into the cell cycle in normal human T cells. Mol Biol Cell 1996;7:1443-54.

3 Bonatz G, Klapper W, Barthe A, Heidorn K, Jonat W, Krupp G, et al. Analysis of telomerase expression and proliferative activity in the different layers of cyclic endometrium. Biochem Biophys Res Commun 1998;253:214-21.

4 Blasco MA. Immunosenescence phenotypes in the telomerase knockout mouse. Springer Semin Immunopathol 2002;24:75-85.

5 Son NH, Murray S, Yanovski J, Hodes RJ, Weng N. Lineage-specific telomere shortening and unaltered capacity for telomerase expression in human $T$ and $B$ lymphocytes with age. J Immunol 2000;165:1191-6.

6 Koetz K, Bryl E, Spickschen K, O'Fallon WM, Goronzy JJ, Weyand CM. T cell homeostasis in patients with rheumatoid arthritis. Proc Natl Acad Sci USA 2000;97:9203-8.

7 Wu K, Higashi N, Hansen ER, Lund M, Bang K, Thestrup-Pedersen K. Telomerase activity is increased and telomere length shortened in T cells from blood of patients with atopic dermatitis and psoriasis. J Immunol 2000; 165:4742-7

8 Klapper W, Singh KK, Heidorn K, Parwaresch R, Krupp G. Regulation of telomerase activity in quiescent immortalized human cells. Biochim Biophys Acta 1998; 1442:120-6.

9 Kurosaka D, Ozawa Y, Yasuda J, Yamada A, Akiyama M, Saito S, et al. Telomerase activity in peripheral blood mononuclear cells from patients with SLE. Ann Rheum Dis 2001:60:1158-9.

10 Katayama Y, Kohriyama K. Telomerase activity in peripheral blood mononuclear cells of systemic connective tissue diseases. J Rheumatol $2001 ; 28: 288-91$.

11 Odendahl M, Jacobi A, Hansen A, Feist E, Hiepe F, Burmester GR, et al. Disturbed peripheral B lymphocyte homeostasis in systemic lupus erythematosus. J Immunol 2000; 165:5970-9.

12 Martens PB, Goronzy JJ, Schaid D, Weyand CM. Expansion of unusual CD4+ $\mathrm{T}$ cells in severe rheumatoid arthritis. Arthritis Rheum 1997;40:1106-14.

13 Bodnar AG Ouellette M, Frolkis M, Holt SE, Chiu CP, Morin GB, et al. Extension of life-span by introduction of telomerase into normal human cells. Science 1998;279:349-52.

14 Homann D, Teyton L, Oldstone MB. Differential regulation of antiviral T-cell immunity results in stable CD8+ but declining CD4+ T-cell memory. Nat Med 2001;7:913-19.

15 Roth A, Yssel H, Pene J, Chavez EA, Schertzer M, Lansdorp PM, et al. Telomerase levels control the lifespan of human T lymphocytes. Blood 2003; 102:849-57. 